\title{
MANAJEMEN LAYANAN BIMBINGAN KONSELING DI MAN PURWOREJO
}

\author{
Achmad Nur Faizin
}

Sekolah Tinggi Agama Islam An-Nawawi, Purworejo

\begin{abstract}
ABSTRACK
In the development of students, guidance and counselors are needed in the education unit. Roles and instructors are considered to be a school psychologist able to provide guidance and guidance in solving various problems of students on a personal or collective scale. This problem that is often encountered by students at the high school level must be resolved through counseling at school.
\end{abstract}

Keywords: counseling guidance services for high school students

\begin{abstract}
ABSTRAK
Dalam perkembangan peserta didik dibutuhkan adanya bimbingan serta pelayan penyuluh pada satuan pendidikan.Peran serta penyuluh dianggap sebagai seorang psikolog sekolah mampu ikut memberikan pengarahan dan bimbingan dalam penyelesaian berbagai masalah peserta didik pada skala personal maupun kolektif. Masalah yang sering kali ditemui para pelajar tingkat sekolah menengah akhir ini harus dapat diselesaikan dengan adanya bimbingan konseling pada sekolah.
\end{abstract}

Kata kunci : pelayanan bimbingan konseling pada peserta didik tingkat Sekolah Menengah Akhir 


\section{PENDAHULUAN}

Peran pendidikan memang sangatlah penting untuk menciptakan generasi penerus yang memiliki kualitas yang baik. Bukan hanya pada bidang akademik saja, namun lulusan pesrta didik harus memiliki sikap yang sesuai dengan norma-norma yang berlaku dalam lingkup keluarga, masyarakat, maupun dalam lingkungan teman sebaya. Melalui jenjang pendidikan peserta didik mampu mengetahui dan mengembangkan potensi-potensi yang dimiliki, serta agar mampu menyalurkan bakat dan minat sesuai dengan keinginannya.

Selain daripada itu pendidikan juga sebagai tempat dan wadah yang bertanggung jawab secara penuh, guna mencerdaskan peserta didik agar menjadi seorang pribadi yang mampu bertanggung jawab, bukan hanyakepada orang lain melainkan jugakepada diri sendiri. Setiap warga negara memiliki hak yang sama untuk mendapatkan pendidikan yang tinggi sesuai pada kemampuannya, hal ini sesuai dengan Undang-undang Dasar 1945 pasal 31 yang menjelaskan bahwa, semua warga negara berhak mendapatkan pendidikan setinggi-tingginya. Dalam hal ini pemerintah memiliki peran sangat penting, untuk menyelenggarakan suatu sistem pendidikan yang mampu meningkatkan kualitas individu dari setiap warga negara tersebut. Bimbingan dan Konseling merupakan bagian dari suatu sistem pendidikan yang dapat membantu peserta didik untuk mengembangkan.potensinya.

Kaitanya dengan hal tersebut sesuai dengan UU No.22 tahun 2013 tentang konsep dasar dan fungsi pendidikan menjelaskan bahwa bimbingan dan konseling memiliki peluang yang sangat lebar dalam keseluruhan sistem pendidikan nasional. Bimbingan dan konseling juga memiliki peran yang penting dalam membantu memajukan pendidikan yang lebih baik, karena dalam Bimbingan dan Konseling memiliki empat bidang layanan yang dapat membantu peserta didik untuk dapat mengembangkan secara maksimal potensi yang ada dalam diri peserta didik tersebut. Menurut Yusuf (2009: 51-57) terdapat empat bidang layanan bimbingan dan konseling yaitu: bimbingan dan konseling akademik (belajar), bimbingan dan konseling pribadi, bimbingan dan konseling sosial, bimbingan dan konseling karir. Bimbingan dan konseling berperan penting dalam mensukseskan dunia pendidikan yang lebih baik, untuk menciptakan semua hal itu tentu dalam pelaksanaan layanan tersebut harus memiliki sistem manajemen yang baik.1

\footnotetext{
${ }^{1}$ Yusuf, Samsu. (2009). Program Bimbingan dan Konseling di Sekolah. Bandung: Rizqi Press.
} 
Dalam pelaksanaan layanan bimbingan dan konseling di sekolah perlu dioptimalkan dengan baik, terkait dengan empat bidang layanan tersebut.

Menurut Sukardi (2003: 29) terdapat tujuh jenis layanan yang terdiri dari layanan orientasi, layanan informasi, layanan penempatan dan penyaluran, layanan pembelajaran, layanan konseling perorangan, layanan bimbingan kelompok, layanan konseling kelompok.2Sejalan dengan hal tersebut Sukardi (2003: 60) juga mengemukakan bahwa terdapat lima rencana kegiatan pendukung bimbingan dan konseling yang terdiri dari aplikasi instrumen, himpunan data, konfrensi kasus, kunjungan rumah, alih tangan kasus. Sebaiknya setiap sekolah melaksanakan keseluruhan bidang layanan, jenis, beserta layanan pendukungnya, karena dengan terlaksananya semua program layanan bimbingan dan konseling dapat membantu peserta didik dalam menyelesaikan persoalan yang dihadapi serta dapat mengembangkan potensi yang dimiliki peserta didik tersebut.3

Namun demikian tidak jarang masih terdapat sekolah yang belum dapat melaksanakan keseluruhan dari jenis layanan Bimbingan dan Konseling. Hal ini bisa dikarenakan oleh beberapa hal yaitu terbatasnya waktu yang dimiliki sekolah, dan kurang memadainya sarana prasarana yang terdapat pada sekolah, selain daripada hal tersebut keberhasilan dari pelaksanaan layanan bimbingan dan konseling juga dapat dilihat dari besarnya keefektifan pelaksanaan tiap jenis layanan pada setiap sekolah. Guru bimbingan dan konseling mempunyai tanggung jawab dalam memberikan fasilitas kepada peserta didik guna mencapai tugas perkembangannya secara maksimal. selaindaripada hal tersebut pelaksanaan layanan bimbingan dan konseling pada suatu sekolah sangatlah penting, dalam hal ini dikarenakan pada pelaksanaan layanan tersebut dapat membantu peserta didik dalam proses pemahaman diri sendiri, serta dapat mengembangkan pontensi yang dimiliki peserta didik(Wibowo 2018).

Namun masih terdapat juga peserta didik yang menganggap bahwa ketika mereka dipanggil ke ruang bimbingan dan konseling peserta didik tersebut masih mendapati suatu masalah,hal tersebutkemudian menyebabkan persepsi peserta didik mengenai pelayananbimbingan dan konseling menjadi kurang baik, hal ini juga bisa terjadi dikarenakanmasih kurangnya sosialisasi dan informasi dari guru bimbingan dan konseling kepada pesrta didik yang menjadi penyebab adanya perspektif demikian, maka dengan demikian guru bimbingan dan konseling mempunyai peran yang sangat penting guna merubah cara pandang peserta didik tersebut(Indhra Musthofa 2019).

\footnotetext{
${ }^{2}$ Sukardi, Dewa Ketut. (2003). Management Bimbingan dan Konseling di Sekolah. Bandung: Alfabeta. 
Sejalan dengan pendapat di atas Junaedi dan Wiryosutomo (2013: 4) tentang hubungan antara persepsi peserta didik terhadap kompetensi kepribadian dan kinerja konselor dengan minat peserta didik untuk memanfaatkan layanan bimbingan dan Konseling di sekolah. Rendahnya minat peserta didik dalam memanfaatkan layanan Bimbingan dan Konseling juga dipengaruhi oleh kurangnya sosialisasi Bimbingan dan Konseling kepada peserta didik, dan dalam pemberian layanan Bimbingan dan Konseling kepada peserta didik di sekolah.4

Hal demikian menjadi indikasi bahwa dalam pelaksanaan layanan bimbingan dan konseling belum sepenuhnya dapat berjalan dengan optimal, padahalpelayanan bimbingan dan konseling diberikan untuk semua siswa, artinya layanan tersebut bersifat global atau menyeluruh, maksudnya yaitu untuk diperuntukan untuk mereka yang memiliki masalah ataupun yang tidak memiliki masalah. Pelaksanaan layanan bimbingan dan konseling bersifat global, artinya bahwa pelaksanaan layanan Bimbingan dan Konseling tersebut diberikan kepada semua siswa adanya pengecualian, dengan demikian diharapkan peserta didik mampu memahami serta memaknai pentingnya pelaksanaan layanan bimbingan dan konseling tersebut. Hal itu dapat terwujud jika guru Bimbingan dan Konseling mampu mensosialisasikan serta memberikan informasi dengan baik serta dapat bersikap ketika berhadapan langsung dengan peserta didik. Dengan hal demikian diharapkan tidak akan timbul kebingungan dari peserta didik mengenai pelaksanaan layanan bimbingan dan konseling yang ada disekolah (Sigit Santoso 2019).

Layanan bimbingan dan konseling merupakan fasilitas sekolah yang seharusnya dapat dimanfaatkan oleh siswa guna dapat mengembangkan potensi yang terdapat pada diri peserta didik tersebut. Pelaksanaan layanan bimbingan dan konseling dapat berdampak pada peserta didik dengan optimal,dengan cara pendekatan seorang guru sebagai sahabat peserta didik tersebut. Melalui pendekatan yang baik, bersikap ramah dan terbuka kepada seluruh peserta didik dengan demikian maka peserta didik dapat dengan mudah menerima bimbingan yang diberikan tersebut dengan baik. Namun demikian, masih ada saja pandangan yang keliru mengenai pelayanan bimbingan dan konseling adalah sebagai polisi sekolah. Sejalan dengan pernyataan tersebut Prayitno dan Amti (2004: 122) masih banyak anggapan bahwa peran konselor di sekolah adalah sebagai polisi sekolah yang harus menjaga dan mempertahankan tata tertib, disiplin,

\footnotetext{
${ }^{4}$ Junaedi, dan Wiryosutomo, Hadi Warsito. (2013). Hubungan Antara Persepsi Siswa Terhadap Kompetensi Kepribadian dan Kinerja Konselor dengan Minat Siswa untuk Memanfaatkan Layanan Bimbingan dan Konseling di Sekolah. Jurnal BK UNESA: Semarang.
} 
dan keamanan sekolah. Dengan hal demikian mampu disimpulkan bahwa pelaksanaan layanan bimbingan dan konseling belum secara optimal dapat berjalan dengan baik.Terdapat permasalahan yang begitumendasar yang biasanya muncul dalam pelaksanaan layanan bimbingan dan konseling Sekolah/Madrasah yaitu mengenai terbatasnya waktu jam untuk Bimbingan dan Konseling sehingga dalam pelaksanaan program bimbingan dan konseling berjalan tidak maksimal (Daimah \& Zainun Wafiqatun Niam 2019).

Idealnya satu guru bimbingan dan konseling menangani 150 siswa. Penelitian ini bertujuan untuk mengetahui bagaimana pelaksanaan layanan bimbingan dan konseling di MAN PURWOREJO tahun ajaran 2019/2020. Melalui pelaksanaan layanan bimbingan konseling mampu meningkatkan bakat dan minat peserta didik. Kualitas pelaksanaan layanan bimbingan dan konseling berpengaruh terhadap keberhasilan layanan bimbingan dan konseling yang diberikan kepada siswa. Sehingga pelaksanaan layanan bimbingan dan konseling di sekolah penting untuk diketahui sebagai dasar untuk mempertahankan dan meningkatkan kualitas layanan bimbingan dan konseling di sekolah. Hasil penelitian ini dapat dijadikan sebagai dasar pengembangan layanan bimbingan dan konseling bagi guru bimbingan dan konseling atau konselor di sekolah untuk dapat memberikan layanan bimbingan dan konseling yang efektif dan sesuai dengan kebutuhan siswa dalam menyelesaikan permasalahan yang dialami siswa.

\section{METODELOGI PENELITIAN}

Penelitian ini menggunakan metode kualitatif dengan pendekatan diskriptif. Pendekatan diskriptif bertujuan untuk menggambarkan, meringkas berbagai kondisi, berbagai situasi atau berbagai variabel yang timbul dimasyarakat yang menjadi obyek penelitian itu metode ini di pilih dengan pertimbangan kesesuaianya dengan karakteristik obyek penelitian. Dalam penelitian ini peneliti sebagai pengamat dengan mengumpulkan data, informasi yang kemudian disusun dan di analisis penulis.Lokasi dalam penelitian ini berada di MAN Purworejo. Alasan dalam pemilihan lokasi ini karena manajemen yang terdapat pada MAN Purworejosudah sangat baik, karena hal demikian dirasa sangatlah penting bagi peneliti untuk mengetahui mengenai pokok pembahasan dalam penelitian ini. Agar sesuai dengan kaidah penelitian kualitatif deskriptif, maka kehadiran peneliti sangatlah penting sebagai pengamat secara penuh karena peneliti merupakan instrumen penting dalam penelitian ini (Adi Wibowo 2019).

Peneliti juga menjadi pelaksana pengumpulan data, informasi, menyusun serta menganalisis data. Peneliti melaksanakn observasi dengan menagamati serta 
wawancara dengan sebaik mungkin, sehinnga mampu memperoleh data yang dibutuhkan guna menunjang laporan penelitian. Untuk memperoleh data peneliti terjun langsung kelapangan.

Sumber data dalam penelitian ini meliputi sumber data dokumenter, sumber lapangan, dan prosedur pengumpulan data mencakup : Observasi, dokumentasi, dan metode interview. Teknis analisis data menggunakan metode : reduktif data, penyajian data, dan juga penarikan kesimpulan.

\section{PEMBAHASAN}

Secara etimologis, bimbingan dan konseling terdiri atas dua kata, yaitu "bimbingan" (terjemahan dari kata "guidance") dan "konseling" (diadopsi dari kata "conseling"). Dalam praktik, bimbingan dan konseling merupakan satu kesatuan kegiatan yang tidak terpisahkan. Keduanya merupakan bagian yang integral. Untuk pemahaman yang yang lebih jelas, dalam uraian berikut pengertian bimbingan dan konseling diuraikan secara terpisah.5

Jadi bimbingan bisa berarti bantuan yang diberikan pembimbing kepada individu agar individu yang dibimbing mencapai kemandirian dengan mempergunakan berbagai bahan, melalui interaksi dan pemberian nasihat serta gagasan dalam suasana asuhan dan berdasarkan norma-norma yang berlaku.6

Tujuan Bimbingan dan Konseling

Bimbingan dan konseling berkenaan dengan perilaku, oleh sebab itu tujuan bimbingan dan konseling adalah dalam rangka: pertama. Membantu mengembangkan kualitas kepribadian individu yang dibimbing atau dikonseling. Kedua, membantu mengembangkan kualitas kesehatan mental klien. Ketiga, membantu mengembangkan perilaku yang lebih efektif pada diri individu dan lingkungannya. Keempat, membantu klien menanggulangi problema hidup dan kehidupannya secara mandiri.7

4 Asas Bimbingan dan Konseling

Dalam penyelenggaraan pelayanan bimbingan dan konseling, ada asas-asas yang dalam melakukannya, yaitu ketentuan yang harus diterapkan dalam pelaksanaan

5 Tohirin. 2007. Bimbingan dan Konseling di Sekolah dan Madrasah Berbasis Intregrasi. Jakarta:

RajaGrafindo Pers.hlm 15

${ }^{6}$ Ibid hal.15

${ }^{7}$ Ibid hal. 36 
pelayanan itu. Asas-asas yang di maksudkan adalah asas kerahasiaan, kesukarelaan, keterbukaan, kekinian, kemandirian, kegiatan, kedinamisan, keterpaduan, kenormatifan, keahlian,alih tangan kasus dan tut wuri handayani. Untuk lebih jelasnya berikut ini akan diuraikan secara terperinci masing-masing asas tersebut sebagai berikut:

Asas kerahasiaan, konselor dituntut dan bertanggung jawab atas kerahasiaan data dan keterangan klien yang menjadi sasaran layanan, data dan keterangan tidak boleh dan tidak layak diketahui oleh pihak lain selain konselor dan klien(Hardiyanti, Irawati, Hasgimianti, Nurhayati Zein 2019).

Asas kesukarelaan, yaitu menghendaki adanya kesukarelaan klien untuk mengikuti, menjalani layanan yang diperlukan baginya.

Asas keterbukaan, yaitu agar menghendaki klien untuk bersifat terbuka dan tidak berpura-pura, baik di dalam memberikan keterangan tentang dirinya sendiri maupun dalam menerima berbagai informasi dan materi dari luar yang berguna untuk pengembangan dirinya(Eko Prayogo 2019).

Asas kekinian, menghendaki agar klien bimbingan dan konseling untuk permasalahan klien yang sekarang. Layanan yang berkenaan dengan masa depan atau kondisi masa lalu dilihat dampak dan kaitannya dengan kondisi yang ada dan apa yang diperbuat sekarang(Moch. Tohet 2019).

Asas kemandirian, yaitu menunjuk pada tujuan umum bimbingan dan konseling, yakni klien diharapkan menjadi individu yang mandiri dengan ciri mengenal dan menerima diri sendiri dan lingkungannya, mampu mengambil keputusan, mengarahkan serta mewujudkan diri sendiri, konselor hendaknya mampu mengarahkan segenap layanan bimbingan dan konseling yang di selenggarakannya bagi perkembangan kemandirian peserta didik.

Asas kegiatan, yaitu menghendaki agar klien berpartisipasi secara aktif di dalam penyelenggaraan layanan bimbingan dan konseling.

Asas kedinamisan, usaha pelayanan bimbingan dan konseling menghendaki terjadinya perubahan pada diri klien, yaitu perubahan tingkah laku ke arah yang lebih baik. Perubahan ini tidaklah sekedar mengulang hal yang sama, yang bersifat monoton, melainkan perubahan yang selalu menuju ke sesuatu pembaharuan, sesuatu yang lebih maju, dinamis sesuai dengan arah perkembangan klien yang dikehendaki.

Asas keterpaduan, pelayanan usaha bimbingan dan konseling berusaha memadukan berbagai aspek kepribadian klien, disamping keterpaduan pada diri klien, 
juga harus diperhatikan keterpaduan isi dan proses layanan yang diberikan.Untuk terselenggaranya asas keterpaduan, konselor perlu memiliki wawasan yang luas tentang perkembangan klien dan aspek-aspek lingkungan klien, serta berbagai sumber yang dapat dipergunakan untuk menangani masalah klien, dan semuanya dipadukan dalam keadaan serasi dan saling menunjang dalam upaya bimbingan dan konseling. 8

Asas kenormatifan, yaitu usaha bimbingan dan konseling tidak boleh bertentangan dengan norma-norma yang berlaku, baik ditinjau dari norma agama, norma adat, norma hukum Negara, norma ilmu, maupun kebiasaan sehari-hari. Kenormatifan ini diterapkan terhadap isi maupun proses penyelenggaraan bimbingan dan konseling.

Asas keahlian, usaha bimbingan dan konseling perlu di lakukan asas ke ahlian secara teratur dan sistematik dengan menggunakan prosedur, teknik, alat yang memadai. Untuk itu para konselor perlu mendapat latihan secukupnya baik teori dan praktik, sehingga akan dicapai keberhasilan usaha pemberian layanan yang terbaik.

Asas alih tangan, dalam pemberiaan layanan bimbingan dan konseling, asas alih tangan jika konselor sudah mengarahkan segenap kemampuannya untuk membantu klien, namun klien belum dapat terbantu sebagaimana yang diharapkan, maka konselor dapat mengirim klien tersebut kepada petugas, badan atau lembaga yang lebih ahli.9

Asas tutwuri handayani, asas ini menunjukkan pada suasana umum yang hendaknya tercipta dalam rangka hubungan keseluruhan antara konselor dan klien. Asas ini menuntut agar pelayanan bimbingan dan konseling tidak hanya dirasakan pada waktu klien mengalami masalah dan menghadap konselor saja, namun diluar hubungan proses bantuan bimbingan dan konseling pun hendaknya dirasakan adanya dan manfaatnya pelayanan bimbingan dan konseling itu.

HASIL

\footnotetext{
${ }^{8}$ Prayitno., Emti, Erman. 1999. Dasar-Dasar Bimbingan Dan Konseling. Jakarta: PT. Rineka Cipta.hlm.118-119

${ }^{9}$ Prayitno., Emti, Erman. 1999. Dasar-Dasar Bimbingan Dan Konseling. Jakarta: PT. Rineka Cipta.hlm.119
} 


\section{A. Manajemen Bimbingan Konseling}

1. Visi dan misi Bimbingan Konseling Madrasah Aliyah Negeri Purworejo

\section{a. Visi}

Visi bimbingan dan konseling adalah terwujudnya layanan bimbingan dan konseling yang profesional dalam memfasilitasi perkembangan peserta didik/konseli menuju pribadi unggul dalam imtak, iptek, tangguh, mandiri dan bertanggung jawab

b. Misi

1) Menyelenggarakan layanan bimbingan dan konseling yang memandirikan peserta didik/konseli berdasarkan pendekatan yang humanis dan multikultur.

2) Membangun kolaborasi dengan guru mata pelajaran, wali kelas, orang tua, dunia usaha dan industri, dan pihak lain dalam rangka menyelenggarakan layanan bimbingan dan konseling

3) Meningkatkan mutu guru bimbingan dan konseling atau konselor melalui kegiatan pengembangan keprofesionalan berkelanjutan.

2. Deskripsi Kebutuhan

Kebutuhan peserta didik/konseli dapat diidentifikasi berdasarkan asumsi teoretik dan hasil asesmen kebutuhan yang dilakukan. Dalam melaksanakan tugasnya, guru Bimbingan dan Konseling terlebih dahulu menyusun daftar kebutuhan (Need Assesment). Tujuan penyusunan instrumen tersebut untuk mengetahui kebutuhan dan permasalahan siswa. Ada beberapa contoh aplikasi instrumen yang dapat digunakan untuk mengetahui kebutuhan siswa, antara lain Daftar Cek Masalah (DCM), Inventori Tugas Perkembangan (ITP), Alat Ungkap Masalah (AUM), Analisis Tugas Perkembangan (ATP), dan lain-lain. Selain itu pengalaman Konselor dalam melaksanakan program pelayanan konseling dan masukan dari berbagai pihak terkait juga dapat digunakan sebagai dasar penyusunan daftar kebutuhan konseling.

Deskripsi Rumusan Kebutuhan

\begin{tabular}{|l|l|lc|}
\hline $\begin{array}{l}\text { BIDANG } \\
\text { LAYANAN }\end{array}$ & ASSESMEN KEBUTUHAN & RUMUSAN KEBUTUHAN \\
\hline PRIBADI & Kualitas ibadah saya pada & Meningkatnya & kualitas \\
\hline
\end{tabular}




\begin{tabular}{|c|c|}
\hline $\begin{array}{l}\text { Tuhan YME masih belum } \\
\text { baik }\end{array}$ & \\
\hline $\begin{array}{l}\text { Saya kadang lupa } \\
\text { bersyukur atas nikmat dan } \\
\text { karunia dari Tuhan YME }\end{array}$ & $\begin{array}{l}\text { Selalu bersyukur atas } \\
\text { nikmat dan karunia Tuhan } \\
\text { YME }\end{array}$ \\
\hline $\begin{array}{l}\text { ya merasa masih sulit } \\
\text { tuk selalu berfikir positif }\end{array}$ & liki pikiran positif \\
\hline $\begin{array}{l}\text { Saya kadang-kadang masih } \\
\text { suka menyontek pada } \\
\text { waktu tes / ujian }\end{array}$ & $\begin{array}{l}\text { Kemampuan menghindari } \\
\text { kebiasaan mencontek saat } \\
\text { ujian }\end{array}$ \\
\hline $\begin{array}{lr}\text { Saya belum tahu } & \text { cara } \\
\text { mengendalikan } & \text { emosi } \\
\text { dengan baik } & \end{array}$ & $\begin{array}{l}\text { uan mengelola } \\
\text { gan baik }\end{array}$ \\
\hline $\begin{array}{l}\text { ham tentang } \\
\text { tahanan diri }\end{array}$ & $\begin{array}{l}\text { Pemahaman mengenai } \\
\text { mekanisme pertahanan diri }\end{array}$ \\
\hline $\begin{array}{l}\text { Saya belt } \\
\text { mengatur } n\end{array}$ & $\begin{array}{l}\text { Keterampilan mengatur } \\
\text { waktu kegiatan }\end{array}$ \\
\hline $\begin{array}{lr}\text { Saya merasa } & \text { masih sedikit } \\
\text { pemahaman } & \text { tentang } \\
\text { kesehatan } & \text { reproduksi } \\
\text { remaja } & \end{array}$ & $\begin{array}{l}\text { Pemahaman tentang } \\
\text { kesehatan repoduksi remaja }\end{array}$ \\
\hline $\begin{array}{l}\text { Saya belum mengetahui } \\
\text { banyak tentang jenis obat- } \\
\text { obat terlarang serta } \\
\text { dampaknya }\end{array}$ & $\begin{array}{l}\text { puan menghindari } \\
\text { arang dan narkoba }\end{array}$ \\
\hline $\begin{array}{l}\text { Saya merasa masih sedikit } \\
\text { pengetahuhan tentang ilmu } \\
\text { kepemimpinan }\end{array}$ & $\begin{array}{l}\text { man tentang ilmu } \\
\text { npian }\end{array}$ \\
\hline $\begin{array}{l}\text { Saya belum paham tentang } \\
\text { mental disorder dan } \\
\text { permasalahannya }\end{array}$ & $\begin{array}{l}\text { Kemampuan menghindari } \\
\text { diri dari penyakit mental }\end{array}$ \\
\hline aya & Ker \\
\hline
\end{tabular}




\begin{tabular}{|c|c|c|}
\hline & masuk sekolah & kejenuhan masuk sekolah \\
\hline & $\begin{array}{lr}\text { Saya merasa } & \text { sulit } \\
\text { menghilangkan kebiasaan } \\
\text { keluar } & \text { malam } \\
\text { (bermain,begadang) }\end{array}$ & $\begin{array}{lr}\text { Kemampuan } & \\
\text { menghilangkan } & \text { kebiasaan } \\
\text { keluar } & \text { malem } \\
\text { (bermain,begadang) }\end{array}$ \\
\hline & $\begin{array}{lr}\begin{array}{l}\text { Saya kadang } \\
\text { membuang }\end{array} & \text { lupa } \\
\text { sembarangan } & \end{array}$ & $\begin{array}{l}\text { Memiliki } \quad \text { kebiasaan } \\
\text { membuang sampah pada } \\
\text { tempatnya }\end{array}$ \\
\hline & $\begin{array}{l}\text { Saya tidak suka kalau } \\
\text { disuruh antri, sementara } \\
\text { yang lain tidak mau tertib } \\
\text { untuk antri }\end{array}$ & Memiliki budaya antri \\
\hline & $\begin{array}{l}\text { Saya sedang memiliki } \\
\text { masalah dengan teman } \\
\text { dekat (pacar) }\end{array}$ & $\begin{array}{ll}\text { Pemahaman } & \text { tentang } \\
\text { dampak pacaran }\end{array}$ \\
\hline SOSIAL & $\begin{array}{l}\text { Saya belum bisa memiliki } \\
\text { kepekaan diri dan sosial }\end{array}$ & $\begin{array}{l}\text { Memiliki kepekaan diri dan } \\
\text { sosial }\end{array}$ \\
\hline & $\begin{array}{l}\text { Saya belum tahu cara } \\
\text { berkomunikasi yang efektif }\end{array}$ & $\begin{array}{l}\text { Kemampuan berkomunikasi } \\
\text { yang baik }\end{array}$ \\
\hline & $\begin{array}{l}\text { Saya belum paham yang } \\
\text { harus dilakuan dengan } \\
\text { adanya pemanasan global }\end{array}$ & $\begin{array}{l}\text { Pemahaman dampak } \\
\text { pemanasan global }\end{array}$ \\
\hline & $\begin{array}{l}\text { Saya belum memahami } \\
\text { etika dan budaya tertib } \\
\text { berlalu lintas }\end{array}$ & $\begin{array}{l}\text { Memiliki etika dan budaya } \\
\text { tertib berlalu lintas }\end{array}$ \\
\hline & $\begin{array}{l}\text { Saya merasa sulit mematuhi } \\
\text { tata tertib sekolah }\end{array}$ & $\begin{array}{l}\text { Kemampuan mematuhi } \\
\text { tata tertib sekolah }\end{array}$ \\
\hline & $\begin{array}{l}\text { Saya kadang masih lupa } \\
\text { mengucapkan kata maaf, } \\
\text { tolong dan terimakasih } \\
\text { dalam pergaulan }\end{array}$ & 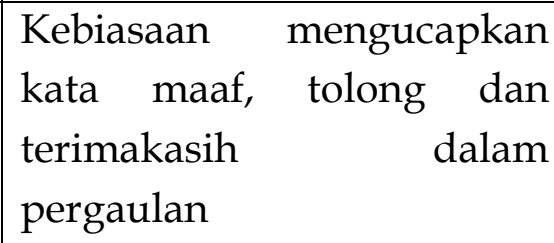 \\
\hline & merasa & Kemampuan \\
\hline
\end{tabular}




\begin{tabular}{|c|c|c|}
\hline & $\begin{array}{l}\text { mengendalikan } \\
\text { ketergantungan } \\
\text { medsos }(\mathrm{fb}, \mathrm{wa}, \mathrm{dll})\end{array}$ & $\begin{array}{l}\text { mengendalikan } \\
\text { ketergantungan } \\
\text { medsos }(\mathrm{fb}, \mathrm{wa}, \mathrm{dll})\end{array}$ \\
\hline & $\begin{array}{l}\text { Saya belum memahami } \\
\text { etika dalam bergaul }\end{array}$ & $\begin{array}{l}\text { Pemahaman tentang etika } \\
\text { bergaul }\end{array}$ \\
\hline & $\begin{array}{l}\text { Saya belum tahu cara } \\
\text { menjaga persahabatan agar } \\
\text { tetap langgeng }\end{array}$ & $\begin{array}{l}\text { Kemampuan membina } \\
\text { persahabatan yang baik }\end{array}$ \\
\hline & $\begin{array}{l}\text { Saya merasa saat ini belum } \\
\text { banyak memiliki teman }\end{array}$ & $\begin{array}{l}\text { Kemampuan membina } \\
\text { hubungan dengan banyak } \\
\text { teman }\end{array}$ \\
\hline & $\begin{array}{l}\text { Saya masih sering terbawa } \\
\text { arus pergaulaan yang } \\
\text { kurang baik }\end{array}$ & $\begin{array}{l}\text { Kemampuan untuk selektif } \\
\text { dalam bergaul }\end{array}$ \\
\hline & $\begin{array}{l}\text { Saya belum tahu tentang } \\
\text { bentuk-bentuk kenakalan } \\
\text { remaja saat ini dan cara } \\
\text { mensikapinya }\end{array}$ & $\begin{array}{ll}\text { Pemahaman } & \text { mengenai } \\
\text { bentuk-bentuk } & \text { kenakalan } \\
\text { remaja } & \\
\end{array}$ \\
\hline & $\begin{array}{l}\text { Saya belum memahami } \\
\text { tawuran pelajar dan } \\
\text { akibatnya }\end{array}$ & $\begin{array}{lr}\text { Kemampuan } & \text { untuk } \\
\text { menghindari } & \text { tawuran } \\
\text { pelajar } & \end{array}$ \\
\hline & $\begin{array}{l}\text { Saya belum memahami } \\
\text { peran sosial pria dan wanita } \\
\text { dengan norma yang ada di } \\
\text { masyarakat }\end{array}$ & $\begin{array}{l}\text { Pemahaman mengenai } \\
\text { peran sosial pria dan wanita } \\
\text { dengan norma yang ada di } \\
\text { masyarakat }\end{array}$ \\
\hline & $\begin{array}{l}\text { Saya belum paham tentang } \\
\text { dampak Sek Bebas, LGBT } \\
\text { dan HIV / AIDS }\end{array}$ & $\begin{array}{l}\text { Pemahaman tentang Sek } \\
\text { Bebas, LGBT, HIV/AIDs }\end{array}$ \\
\hline BELAJAR & $\begin{array}{lll}\text { Saya merasa } & \text { belum } \\
\text { menemukan cara } & \text { belajar } \\
\text { yang efektif } & & \end{array}$ & $\begin{array}{l}\text { Keterampilan belajar efektif } \\
\text { dan efisien }\end{array}$ \\
\hline & Saya belum bisa membuat & Keterampilan \\
\hline
\end{tabular}




\begin{tabular}{|c|c|}
\hline $\begin{array}{l}\text { peta pikiran (mind } \\
\text { mapping) }\end{array}$ & $\lg$ \\
\hline $\begin{array}{l}\text { Saya belum paham cara } \\
\text { kerja otak kiri dan otak } \\
\text { kanan }\end{array}$ & $\begin{array}{l}\text { nai cara } \\
\text { anan }\end{array}$ \\
\hline $\begin{array}{l}\text { Saya belum tahu cara untuk } \\
\text { membangkitkan semangat } \\
\text { belajar }\end{array}$ & $\begin{array}{l}\text { Semangat belajar yang } \\
\text { tinggi }\end{array}$ \\
\hline $\begin{array}{lr}\text { Saya masih suka menunda- } \\
\text { nunda } & \text { tugas } \\
\text { sekolah/pekerjaan } & \text { rumah } \\
(\mathrm{PR}) & \end{array}$ & $\begin{array}{l}\text { Kedisiplinan } \\
\text { menyelesaikan } \\
\text { sekolah }\end{array}$ \\
\hline $\begin{array}{l}\text { Saya merasa kesulitan } \\
\text { dalam memahami pelajaran } \\
\text { tertentu }\end{array}$ & $\begin{array}{l}\text { Kemampuan } \\
\text { menyelesaikan kesulitan } \\
\text { dalam memahami pelajaran } \\
\text { tertentu }\end{array}$ \\
\hline $\begin{array}{l}\text { Saya semangat belajar, } \\
\text { kalau ada tes atau ujian saja }\end{array}$ & $\begin{array}{l}\text { Semangat belajar, tidak } \\
\text { hanya kalau ada tes atau } \\
\text { ujian saja }\end{array}$ \\
\hline $\begin{array}{l}\text { Saya merasa sulit untuk } \\
\text { belajar kelompok }\end{array}$ & $\begin{array}{l}\text { mpuan untuk belajar } \\
\text { pok }\end{array}$ \\
\hline $\begin{array}{l}\text { Saya belum paham cara } \\
\text { memilih } \\
\text { bimbingan belajar yang baik }\end{array}$ & $\begin{array}{l}\text { Kemampuan memilih } \\
\text { lembaga bimbingan belajar } \\
\text { yang baik }\end{array}$ \\
\hline $\begin{array}{l}\text { Saya belum dapat } \\
\text { memanfaatkan teknologi } \\
\text { informasi untuk belajar }\end{array}$ & $\begin{array}{l}\text { Keterampilan } r \text { untuk } \\
\text { memanfaatkan teknologi } \\
\text { informasi untuk belajar }\end{array}$ \\
\hline $\begin{array}{l}\text { Saya masih belum bisa } \\
\text { belajar secara rutin }\end{array}$ & $\begin{array}{l}\text { Memiliki kebiasaan belajar } \\
\text { secara rutin }\end{array}$ \\
\hline $\begin{array}{l}\text { Saya merasa takut bertanya } \\
\text { atau menjawab di kelas }\end{array}$ & $\begin{array}{l}\text { Memiliki keberanian } \\
\text { bertanya dan menjawab di } \\
\text { kelas }\end{array}$ \\
\hline
\end{tabular}




\begin{tabular}{|c|c|c|}
\hline & $\begin{array}{l}\text { Saya jarang sekali } \\
\text { mengunjungi perpustakaan } \\
\text { untuk membaca }\end{array}$ & $\begin{array}{l}\text { Kebiasaan membaca yang } \\
\text { tinggi }\end{array}$ \\
\hline \multirow[t]{6}{*}{ KARIR } & $\begin{array}{l}\text { Saya terpaksa harus bekerja } \\
\text { untuk mencukupi } \\
\text { kebutuhan hidup }\end{array}$ & $\begin{array}{l}\text { Kemampuan memperoleh } \\
\text { penghasilan untuk biaya } \\
\text { hidup }\end{array}$ \\
\hline & $\begin{array}{l}\text { Saya merasa belum banyak } \\
\text { tahu tentang jenis-jenis } \\
\text { profesi/pekerjaan di } \\
\text { masyakarat }\end{array}$ & $\begin{array}{l}\text { Mengidentifikasi jenis-jenis } \\
\text { profesi/pekerjaan }\end{array}$ \\
\hline & $\begin{array}{l}\text { Saya belum memahamai } \\
\text { program studi yang ada di } \\
\text { Perguruan Tinggi }\end{array}$ & $\begin{array}{l}\text { Pemahaman mengenai } \\
\text { program studi di Perguruan } \\
\text { Tinggi }\end{array}$ \\
\hline & $\begin{array}{l}\text { Saya belum } \text { paham } \\
\text { hubungan antara bakat, } \\
\text { minat, pendidikan dan } \\
\text { pekerjaan }\end{array}$ & $\begin{array}{l}\text { Pemahaman mengenai } \\
\text { hubungan bakat, minat, } \\
\text { pendidikan dan pekerjaan }\end{array}$ \\
\hline & $\begin{array}{l}\text { Saya masih memiliki } \\
\text { keraguan dengan pilihan } \\
\text { cita-cita/karir masa depan }\end{array}$ & $\begin{array}{l}\text { Mengidentifkasi pilihan } \\
\text { karir atau cita-cita yang } \\
\text { sesuai dengan dirinya }\end{array}$ \\
\hline & $\begin{array}{l}\text { Saya belum mengetahui } \\
\text { tentang seleksi masuk } \\
\text { perguruan tinggi }\end{array}$ & $\begin{array}{l}\text { Pemahaman mengenai } \\
\text { seleksi mahasiswa di } \\
\text { Perguruan tinggi }\end{array}$ \\
\hline
\end{tabular}

\section{Komponen Program}

Komponen program bimbingan dan konseling di Mandrasah Aliyah Negeri Purworejo meliputi : (1) layanan dasar, (2) layanan peminatan dan perencanaan individual, (3) Layanan Responsif, dan (4) dukungan sistem. Berikut penjelasan mengenai masing-masing komponen

a. LayananDasar

Layanan dasar adalah proses pemberian bantuan kepada semua peserta didik/konseli yang berkaitan dengan pengembangan sikap, pengetahuan, dan keterampilan dalam bidang pribadi, sosial, belajar, dan karir sebagai pengejawantahan tugas-tugas perkembangan mereka. Layanan dasar merupakan 
inti pendekatan perkembangan yang diorganisasikan berkenaan dengan pengetahuan tentang diri dan orang lain, perkembangan belajar, serta perencanaan dan eksplorasi karir. Layanan dasar pada sekolah dasar dilaksanakan dalam aktivitas yang langsung diberikan kepada peserta didik/konseli adalah bimbingan kelompok, bimbingan klasikal, dan bimbingan lintas kelas. Aktivitas yang dilaksanakan melalui media adalah papan bimbingan, leaflet dan media inovatif bimbingan dan konseling. Bagi guru kelas yang menjalankan fungsi sebagai guru bimbingan dan konseling, layanan bimbingan klasikal dapat diintegrasikan dalam kegiatan pembelajaran tematik.

\section{b. LayananResponsif}

Layanan responsif adalah layanan untuk memenuhi kebutuhan jangka pendek peserta didik, atau masalah-masalah yang dialami peserta didik/konseli yang bersumber dari lingkungan kehidupan pribadi, sosial, belajar, dan karir. Layanan terdiri atas konseling individual, konseling kelompok, konsultasi, konferensi kasus, referal dan advokasi. Sementara aktivitas layanan responsif melalui media adalah konseling melalui elektronik dan kotak masalah. Pada konteks layanan responsif di Sekolah Dasar, guru bimbingan dan konseling atau konselor memberikan intervensi secara singkat. Pada layanan responsif juga dilakukan advokasi yang menitikberatkan pada membantu peserta didik/konseli untuk memiliki kesempatan yang sama dalam mencapai tugas-tugas perkembangan. Guru bimbingan dan konseling atau konselor menyadari terdapat rintangan-rintangan bagi peserta didik yang disebabkan oleh disabilitas, jenis kelamin, suku bangsa, bahasa, orientasi seksual, status sosial ekonomi, pengaruh orangtua, keberbakatan, dan sebagainya. Gurubimbingan dan konseling atau konselor harus memberikan advokasi agar semua peserta didik/konseli mendapatkan perlakuan yang setara selama menempuh pendidikan di Sekolah Dasar.

c. Layanan Peminatan dan Perencanaan Individual PesertaDidik

Layanan peminatan dan perencanaan individual merupakan proses pemberian bantuan kepada semua peserta didik/konseli dalam membuat dan mengimplementasikan rencana pribadi, sosial, belajar, dan karir. Tujuan utama layanan ini ialah membantu peserta didik belajar memantau dan memahami pertumbuhan danperkembangannya sendiri dan mengambil tindakan secara proaktif terhadap informasi tersebut Layanan peminatan dan perencanaan individual berisi aktivitas membantu setiap peserta didik untuk mengembangkan dan meninjau minat dan perencanaan pribadi, sosial, belajar, 
dan karir. Aktivitas dimulai sejak peserta didik masih di sekolah dasar dan berlanjut terus sampai di sekolah menengah. Rencana yang telah dibuat oleh peserta didik ditinjau dan diperbaharui secara berkala dan didokumentasikan di dalam profil peserta didik, misalnya dalam bentukgrafik.

Aktivitas layanan peminatan dan perencanaan individual yang langsung diberikan kepada peserta didik dapat berupa kegiatan bimbingan klasikal, konseling individual, konseling kelompok, bimbingan kelas besar atau lintas kelas, bimbingan kelompok, konsultasi dan kolaborasi. Aktivitas peminatan dan perencanaan individual di Sekolah Dasar terintegrasi dengan kegiatan ekstrakurikuler. Pemilihan kegiatan ekstrakurikuler juga dapat menggambarkan minat peserta didik pada aktivitas tertentu. Guru bimbingan dan konseling atau konselor dapat memberikan informasi tentang perencanaan pribadi, akademik dan karir dalam pemilihan kegiatan ekstra kurikuler bagi peserta didik.

\section{d. DukunganSistem}

Dukungan sistem merupakan komponen pelayanan dan kegiatan manajemen, tata kerja infrastruktur dan pengembangan keprofesionalan konselor secara berkelanjutan yang secara tidak langsung memberikan bantuan kepada peserta didik atau memfasilitasi kelancaran perkembangan peserta didik. Aktivitas yang dilakukan dalam dukungan sistem adalah (1) administrasi, yang di dalamnya termasuk melaksanakan dan menindaklanjuti asesmen, kunjungan rumah, menyusun dan melaporkan program bimbingan dan konseling, membuat evaluasi, dan melaksanakan administrasi dan mekanisme bimbingan dan konseling, serta (2) kegiatan tambahan dan pengembangan profesi, bagi konselor atau guru kelas yang berfungsi sebagai guru bimbingan dan konseling, kegiatan pengembangan profesi dilaksanakan sesuai dengan tugasnya sebagai guru kelas dengan diperkaya oleh kegiatan pelatihan atau lokakarya tentang bimbingan dan konseling untuk memperkuat kompetensi dalam menjalankan fungsi sebagai guru bimbingan dan konseling ataukonselor.

Pengembangan Keprofesian Berkelanjutan (guru sebagai pembelajar) bagi konselor atau guru bimbingan dan konseling dapat dilakukan dengan moda tatap muka, daring dan kombinasi antara tatap muka dan daring.

\section{Bidang Layanan}

Bimbingan dan konseling pada satuan pendidikan mencakup empat bidang layanan, yaitu bidang layanan yang memfasilitasi perkembangan pribadi, sosial, 
belajar, dan karir yang merupakan satu kesatuan utuh dapat dipisahkan dalam setiap diri individu peserta didik/konseli.

a. Pribadi

Suatu proses pemberian bantuan dari guru bimbingan dan konseling atau konselor kepada peserta didik / konseli untuk memahami, menerima, mengarahkan, mengambil keputusan, dan merealisasikan keputusannya secara bertanggung jawab tentang perkembangan aspek pribadinya, sehingga dapat mencapai perkembangan secara optimal dan mencapai kebahagiaan, kesejahteraan dan keselamatan dalam kehidupannya.

Aspek perkembangan peserta didik/konseli yang dikembangkanmeliputi (1) memahami potensi diri dan memahami kelebihan dan kelemahannya, baik kondisi fisik maupun psikis, (2) mengembangkan potensi untuk mencapai kesuksesan dalam kehidupannya, (3) menerima kelemahan kondisi diri dan mengatasinya secarabaik.

b. Sosial

Suatu proses pemberian bantuan dari konselor kepada peserta didik/konseli untuk memahami lingkungannya dan dapat melakukan interaksi sosial secara positif, terampil berinteraksi sosial, mampu mengatasi masalahmasalah sosial yang dialaminya, mampu menyesuaikan diri dan memiliki keserasian hubungan dengan lingkungan sosialnya sehingga mencapai kebahagiaan dan kebermaknaan dalam kehidupannya.

Aspek perkembangan peserta didik/konseli yang dikembangkan meliputi (1) berempati terhadap kondisi orang lain, (2) memahami keragaman latar sosial budaya, (3) menghormati dan menghargai orang lain, (4) menyesuaikan dengan nilai dan norma yang berlaku, (5) berinteraksi sosial yang efektif, (6) bekerjasama dengan orang lain secara bertanggung jawab, dan (8) mengatasi konflik dengan orang lain berdasarkan prinsip yang salingmenguntungkan.

c. Belajar

Proses pemberian bantuan kepada peserta didik/ konseli dalam mengenali potensi diri untuk belajar, memiliki sikap dan keterampilan belajar, terampil merencanakan pendidikan, memiliki kesiapan menghadapi ujian, memiliki 
kebiasaan belajar teratur dan mencapai hasil belajar secara optimal sehingga dapat mencapai kesuksesan, kesejahteraan, dan kebahagiaan dalam kehidupannya.

Aspekperkembangan yang dikembangkan meliputi;

1) Menyadari potensi diri dalam aspek belajar dan memahami berbagai hambatan belajar

2) Memiliki sikap dan kebiasaan belajar yang positif;

3) Memiliki motif yang tinggi untuk belajar sepanjang hayat;

4) Memiliki keterampilan belajar yang efektif;

5) Memiliki keterampilan perencanaan dan penetapan pendidikan selanjutnya; dan

6) Memiliki kesiapan menghadapi ujian

d. Karir

Proses pemberian bantuan oleh guru bimbingan dan konseling atau konselor kepada peserta didik/konseli untuk mengalami pertumbuhan, perkembangan, eksplorasi, aspirasi dan pengambilan keputusan karir sepanjang rentang hidupnya secara rasional dan realistis berdasar informasi potensi diri dan kesempatan yang tersedia di lingkungan hidupnya sehingga mencapai kesuksesan dalam kehidupannya.

Aspek perkembangan yang dikembangkan meliputi; (1) pengetahuan konsep diri yang positif tentang karir, (2) kematangan emosi dan fisik dalam membuat keputusan karir, (3) Kesadaran pentingnya pencapaian prestasi untuk mendapatkan kesempatan karir, (4) Kesadaran hubungan antara pekerjaan dan belajar, (5) Keterampilan untuk memahami dan menggunakan informasi karir, (6) Kesadaran hubungan antara tanggung jawab personal, kebiasaan bekerja yang baik dan kesempatan karir, (7) Kesadaran bagaimana karir berhubungan dengan fungsi dan kebutuhan di masyarakat, (8) Kesadaran tentang perbedaan pekerjaan dan perubahan peran laki-laki dan perempuan.

\section{RencanaKegiatan/Operasioal (Action Plan)}

Rencana kegiatan (action plan) bimbingan dan konseling merupakan rencan yang menguraikan tindakan-tindakan yang diperlukan untuk mencapai tujuan yang didapat dari hasil assesmen terhadap kondisi peserta didik/konseli serta standar 
kompetensi kemandirian siswa. Rencana kegiatan bimbingan dan konseling terdiri dari beberapa komponen, yaitu :

a. Bidang layanan

Berisi tentang bidang layanan bimbingan dan konseling

b. Tujuan Layanan

Berisi tentang tujuan yang akan dicapai yang berbasis hasil asesmen, tugas perkembangan atau standar kompetensi kemandirian siswa.

c. Komponenlayanan

Terdiri dari empat komponen yaitu (1) layanan dasar, (2) layanan responsif, (3) peminatan dan perencanaan individual, (4) dukungan system

d. Strategilayanan,

Merupakan kegiatan/strategi layanan yang dilakukan dan disesuaikan dengan komponen layanan. Contohnya, untuk komponen layanan dasar, strategi layanan yang dapat dilaksanakan adalah bimbingan.

e. Kelas,

Berisi kelas yang akan mendapatkan layanan bimbingan dan konseling

f. Materi,

Berisi tentang tema/topik materi yang akan dibahas untuk mencapai tujuan.

g. Metode,

Berisi teknik/strategi kegiatan layanan bimbingan dan konseling yang akandilakukan.

h. Alat/media,

Berisi alat dan media yang akan digunakan misalnya power point presentation, kertas kerja dansebagainya.

i. Evaluasi,

Berisi jenis dan alat evaluasi yang digunakan untuk memastikan ketercapaian tujuanlayanan. 
j. Ekuivalensi,

Berisi penyetaraan kegiatan bimbingan dan konseling yang dilakukan dengan jumlah jam. (secara rinci dapat dilihat pada Lampiran Permendikbud No.111 Tahun 2014 tentang Bimbingan dan Konseling pada Pendidikan Dasar dan Menengah).

6. Rencana Evaluasi. Pelaporan Dan Tindak Lanjut

a. Evaluasi

Evaluasi merupakan langkah penting dalam manajemen pelayanan bimbingan dan konseling (BK). Evaluasi secara umum ditujukan untuk mengetahui tingkat keterlaksanaan kegiatan dan ketercapaian tujuan program yang telah ditetapkan. Dalam evaluasi program bimbingan dan konseling terdapat 2 (dua) jenis evaluasi, yaitu evaluasi proses dan evaluasi hasil.

Evaluasi proses adalah kegiatan evaluasi yang dilakukan melalui analisis hasil penilaian proses selama kegiatan pelayanan bimbingan dan konseling berlangsung. Fokus penilaian adalah keterlibatan unsur-unsur dalam pelaksanaan kegitan bimbingan dan konseling.

Evaluasi hasil adalah kegiatan evaluasi yang dilakukan untuk memperoleh informasi tentang keefektifan layanan bimbingan dan konseling dilihat dari hasilnya. Evaluasi hasil pelayanan bimbingan dan konseling ditujukan pada hasil yang diacapi oleh peserta didik yang menjalin pelayanan bimbingan dan konseling. Fokus penilaian dapat diarahkan pada berkembangnya :

1) Pemahaman diri, sikap, dan prilaku yang diperoleh berkaitan dengan materi / topik / masalah yang dibahas

2) Perasaan positif sebagai dampak dari proses atau meteri/topik/masalah yang dibahas

3) Rencana kegiatan yang akan dilaksanakan pasca layanan dalam rangka mewujudkan upaya pengembangan/pengetasan masalah.

Langkah-langkah pelaksanaan :

1) Penyusunan rencana evaluasi

2) Pengumpulan Data

3) Analisa dan interpretasi data 


\section{b. Pelaporan}

Pelaporan merupakan langkah lanjutan setelah evaluasi. Isi dalam pelaporan lebih bersifat mendeskripsikan dan memberi uraian analisis terhadap hasil-hasil yang telah dicapai dalam kegiatan evaluasi sebelumnya. Pelaporan pada hakikatnya merupakan kegiatan menyusun dan mendeskripsikan seluruh hasil yang telah dicapai dalam evaluasi proses maupun hasil dalam format laporan yang dapat memberikan informasi kepada seluruh pihak yang terlibat tentang keberhasilan dan kekurangan dari program bimbingan dan konseling yang telah dilakukan

Terdapat tiga aspek pokok yang perlu diperhatikan dalam penyusunan laporan yaitu :

1) Sistematika laporan hendaknya logis dan dapat dipahami

2) Deskripsi laporan yang disusun hendaknya memperhatikan kaidah penulisan dan kebahasaan yang telah dilakukan

3) Laporan pelaksanaan program bimbingan dan konseling harus dilaporkan secara akurat dan tepat waktu

Langkah-langkah dalam penyusunan laporan :

1) Tahap persiapan

2) Pengumpulan dan penyajian data

3) Penulisan laporan

4) Sistematika laporan

\section{c. Tindak Lanjut}

Tindak lanjut dalam kegiatan evaluasi merupakan kegiatan yang dilakukan untuk menindaklanjuti hasil pelaksanaan pelayanan bimbingan dan konseling. Berdasarkan data dan informasi yang diperoleh dari hasil evaluasi, guru BK atau konselor dapat memikirkan ulang keseluruhan program yang telah dilaksanakan dengancara membuat desain ulang atau merevisi seluruh program atau beberapa bagian dari program yang dianggap belum begitu efektif.

Langkah-langkah tindak lanjut :

1) Menentukan aspek-aspek perbaikan atau peningkatan yang akan dilakukan. 
2) Menyusun ulang desain program secara umum atau layanan bimbingan dan konseling tertentu dalam rangka perbaikan atau pengembangan

3) Melaksanakan kegiatan tindak lanjut sesuai dengan aspek-aspek yang akan diperbaiki atau dikembangkan dan alokasi waktu yang telah ditentukan.

7. Sarana Dan Prasarana Bimbingan Dan Konseling

Prasarana pokok yang diperlukan ialah ruang bimbingan dan konseling yang cukup memadai. Ruang dimaksud hendaknya diatur sedemikian rupa sehingga peserta dididk yang berkunjung merasa senang dan nyaman, serta ruangan tersebut dapat digunakan untuk pelaksanaan berbagai jenis kegiatan layanan bimbingan dan konseling baik individu maupun kelompok sesuai dengan asas-asas dan kode etik bimbingan dan konseling.

Sedangkan Sarana dan prasarana berisi fasilitas dan perlengkapan yang mendukung terhadap keterlaksanaan program bimbingan dan konseling. Sarana yang akan digunakan dalam kegiatan pelayanan bimbingan dan konseling meliputi :

a. Alat pengumpul data, baik tes maupun non tes, yaitu :

1) Angket Kebutuhan Peserta Didik / Aplikasi AKPD

2) Sosiometri

3) Alat Ungkap Pemahaman Diri

4) Alat Penelusuran Minat Peserta Didik SMA/MA

5) Alat Ungkap Masalah Seri PTSDL

6) Inventori Tugas Perkembangan

7) Daftar Cek Masalah

8) Alat Ungkap Masalah

9) Catatan Anekdot

b. Alat penyimpan data, khususnya dalam bentuk himpunan data yaitu :

1) Cummulative Record

2) Basis Data Prestasi Akademik

3) Daftar Peserta Didik Asuh 
c. Kelengkapan penunjang teknis yaitu :

1) Data informasi meliputi: Peta Peserta Didik

2) Paket bimbingan meliputi : Paket Materi Klasikal

3) Alat bantu bimbingan meliputi : Buku Saku, Poster.

d. Perlengkapan administrasi, yaitu :

1) Alat tulis

2) Format rencana kegiatan

3) Blanko laporan kegiatan

Sedangkan prasarana penunjang layanan : Ruang bimbingan dan konseling terdiri atas : ruang tamu, ruang kerja, ruang bimbingan dan konseling kelompok/diskusi, ruang konseling individu.

8. AnggaranDan Biaya

Anggaran biaya menyesuaikan dengan anggaran sekolah yang dialokasikan untuk kegiatan bimbingan dan Konseling dengan rincian kebutuhan sebagai berikut :

Rencana anggaran berisi uraian jenis kegiatan dan rincian besar anggaran yang dibutuhkan. Jumlah besar anggaran menunjukkan kebutuhan besaran anggaran untuk mendukung keterlaksanaan program bimbingan dan konseling. Rencana anggaran disusun untuk mendukung implementasi program secara cermat, rasional dan realistik.

Adapun rencana anggaran kegiatan bimbingan dan konseling pada tahun ini adalah sebagai berikut :

\begin{tabular}{|c|c|c|c|}
\hline $\mathrm{NO}$ & KEGIATAN & VOLUME & JUMLAH \\
\hline A & LAYANAN BK & & \\
\hline 1 & Home visit & 1 orang $x \quad 10 \quad$ OB & Rp. 1.000.000,- \\
\hline 2 & Pembuatan media BK & 2 Paket $x$ Rp. 1000.000,- & Rp. 2.000.000,- \\
\hline$\beta$ & Mengikuti & 1 Orang $\times 4$ Keg & Rp. 750.000,- \\
\hline & MGBK Kedu dan & & \\
\hline & & & \\
\hline B & BAHAN & & \\
\hline 1 & Kertas HVS A4 70 gram & $20 \operatorname{Rim} \times$ Rp. 40.000,- & $\operatorname{Rp}, \quad 800.000,-$ \\
\hline
\end{tabular}




\begin{tabular}{|c|c|c|c|}
\hline 2 & Kertas HVS F4 70 gram & $5 \operatorname{Rim} \times$ Rp. $45.000,-$ & Rp. $225.000,-$ \\
\hline 3 & Stapler & $3 \operatorname{Rim} \times$ Rp. 20.000,- & 60.000,- \\
\hline 4 & Isi stapler & 1 Box x Rp.25.000,- & $25.000,-$ \\
\hline 5 & Spidol white board & 4 Box x Rp. 100.000,- & Rp. 400.000,- \\
\hline 6 & Penghapus white board & 2 Buah x Rp. 15.000,- & Rp. $30.000,-$ \\
\hline 7 & Flash disk & 2 Buah x Rp. 85.000,-- & Rp. $170.000,-$ \\
\hline 8 & CD RW & 1 Box $x$ Rp. $150.000,-$ & Rp. 150.000,- \\
\hline 9 & Toner printer & 2 Buah x Rp. 970.000,-- & Rp. 1.970.000,- \\
\hline 10 & Refil Toner printer & 4 Buah x Rp. 350.000,- & Rp. 1.400.000,- \\
\hline 11 & Penggandaan & 1 Paket x Rp. 5.000.000,- & Rp. 5.000.000,- \\
\hline $\bar{C}$ & SARANA & & \\
\hline 1 & Pembuatan sekat untuk & 1 Paket $x$ Rp. 2.000.000,- & Rp. 2.000.000,- \\
\hline 2 & Pengadaan komputer & 1 Set x Rp. 8.500.000,- & Rp. 8.500.000,- \\
\hline $\mathrm{D}$ & Total Biaya & & Rp. 23.500.000,- \\
\hline
\end{tabular}

\section{ProgramSemesteran}

Setelah membuat rencana kegiatan yang akan dilakukan selama satu tahun, kemudian mendistribusikan komponen layanan dan strategi kegiatan dalam progam semesteran dalam bentuk yang lebih rinci.

Terdapat beberapa komponen dalam program semesteran, yaitu :

a. Bulan dan komponen program

b. Layanan Dasar

Berisi tentang strategi layanan dan topik/tema layanan dalam komponen layanan dasar, seperti bimbingan klasikal dengan tema yang sudah dibuat dalam rencana kegiatan

c. Layanan Peminatan dan Perencanaan Individual

Berisi tentang strategi layanan dan topik/tema dalam komponen layanan perencanaan individual misalnya bimbingan klasikal dengan tema memiliha sekolah / studi lanjutan ke jenjang yang lebih tinggi

d. Layanan Responsif 
Berisi strategi layanan dan topik/tema (bila ada) dalam komponen layanan responsif, misalnya : konseling kelompok dengan tema/topik "3 Kata Penting dalam Pergaulan"

e. Dukungan sistem

Berisis tentang strategi kegiatan dalam dukungan sistem seperti pengembangan jejaring, kegiatan manajemen dan PKB.

E. SIMPULAN

A. Visi dan misi Bimbingan Konseling Madrasah Aliyah Negeri Purworejo

a. Visi

Visi bimbingan dan konseling adalah terwujudnya layanan bimbingan dan konseling yang profesional dalam memfasilitasi perkembangan peserta didik/konseli menuju pribadi unggul dalam imtak, iptek, tangguh, mandiri dan bertanggung jawab

b. Misi

4)Menyelenggarakan layanan bimbingan dan konseling yang memandirikan peserta 
didik/konseli berdasarkan pendekatan yang humanis dan multikultur.

5)Membangun kolaborasi dengan guru mata pelajaran, wali kelas, orang tua, dunia usaha dan industri, dan pihak lain dalam rangka menyelenggarakan layanan bimbingan dan konseling

6)Meningkatkan mutu guru bimbingan dan konseling atau konselor melalui kegiatan pengembangan keprofesionalan berkelanjutan.

\section{B.Komponen Program}

Komponen program bimbingan dan konseling di Mandrasah Aliyah Negeri Purworejo meliputi : (1) layanan dasar, (2) layanan peminatan dan perencanaan individual, (3) Layanan Responsif, dan (4) dukungan sistem. Berikut penjelasan mengenai masing-masing komponen

\section{a. LayananDasar}

Layanan dasar adalah proses pemberian bantuan kepada semua peserta didik/konseli yang berkaitan dengan pengembangan sikap, pengetahuan, dan keterampilan dalam bidang pribadi, sosial, belajar, dan karir sebagai pengejawantahan tugas-tugas perkembangan mereka. Layanan dasar merupakan inti pendekatan perkembangan yang diorganisasikan berkenaan dengan pengetahuan tentang diri dan orang lain, perkembangan belajar, serta perencanaan dan eksplorasi karir. Layanan dasar pada sekolah dasar dilaksanakan dalam aktivitas yang langsung diberikan kepada peserta didik/konseli adalah bimbingan kelompok, bimbingan klasikal, dan bimbingan lintas kelas. Aktivitas yang dilaksanakan melalui media adalah papan bimbingan, leaflet dan media inovatif bimbingan dan konseling. Bagi guru kelas yang menjalankan fungsi sebagai guru bimbingan dan konseling, layanan bimbingan klasikal dapat diintegrasikan dalam kegiatan pembelajaran tematik.

b. LayananResponsif 
Layanan responsif adalah layanan untuk memenuhi kebutuhan jangka pendek peserta didik, atau masalah-masalah yang dialami peserta didik/konseli yang bersumber dari lingkungan kehidupan pribadi, sosial, belajar, dan karir. Layanan terdiri atas konseling individual, konseling kelompok, konsultasi, konferensi kasus, referal dan advokasi. Sementara aktivitas layanan responsif melalui media adalah konseling melalui elektronik dan kotak masalah. Pada konteks layanan responsif di Sekolah Dasar, guru bimbingan dan konseling atau konselor memberikan intervensi secara singkat. Pada layanan responsif juga dilakukan advokasi yang menitikberatkan pada membantu peserta didik/konseli untuk memiliki kesempatan yang sama dalam mencapai tugas-tugas perkembangan. Guru bimbingan dan konseling atau konselor menyadari terdapat rintangan-rintangan bagi peserta didik yang disebabkan oleh disabilitas, jenis kelamin, suku bangsa, bahasa, orientasi seksual, status sosial ekonomi, pengaruh orangtua, keberbakatan, dan sebagainya. Gurubimbingan dan konseling atau konselor harus memberikan advokasi agar semua peserta didik/konseli mendapatkan perlakuan yang setara selama menempuh pendidikan di Sekolah Dasar.

c. Layanan Peminatan dan Perencanaan Individual PesertaDidik

Layanan peminatan dan perencanaan individual merupakan proses pemberian bantuan kepada semua peserta didik/konseli dalam membuat dan mengimplementasikan rencana pribadi, sosial, belajar, dan karir. Tujuan utama layanan ini ialah membantu peserta didik belajar memantau dan memahami pertumbuhan danperkembangannya sendiri dan mengambil tindakan secara proaktif terhadap informasi tersebut Layanan peminatan dan perencanaan individual berisi aktivitas membantu setiap peserta didik untuk mengembangkan dan meninjau minat dan perencanaan pribadi, sosial, belajar, dan karir. Aktivitas dimulai sejak peserta didik masih di sekolah dasar dan berlanjut terus sampai di sekolah menengah.

Rencana yang telah dibuat oleh peserta didik ditinjau dan diperbaharui secara berkala dan didokumentasikan di dalam profil peserta didik, misalnya dalam bentukgrafik. Aktivitas layanan peminatan dan perencanaan individual yang langsung diberikan kepada peserta didik dapat berupa kegiatan bimbingan klasikal, konseling individual, konseling kelompok, bimbingan kelas besar atau lintas kelas, bimbingan kelompok, konsultasi dan kolaborasi. Aktivitas peminatan dan perencanaan individual di Sekolah Dasar terintegrasi dengan kegiatan 
ekstrakurikuler. Pemilihan kegiatan ekstrakurikuler juga dapat menggambarkan minat peserta didik pada aktivitas tertentu. Guru bimbingan dan konseling atau konselor dapat memberikan informasi tentang perencanaan pribadi, akademik dan karir dalam pemilihan kegiatan ekstra kurikuler bagi peserta didik.

\section{d. DukunganSistem}

Dukungan sistem merupakan komponen pelayanan dan kegiatan manajemen, tata kerja infrastruktur dan pengembangan keprofesionalan konselor secara berkelanjutan yang secara tidak langsung memberikan bantuan kepada peserta didik atau memfasilitasi kelancaran perkembangan peserta didik. Aktivitas yang dilakukan dalam dukungan sistem adalah (1) administrasi, yang di dalamnya termasuk melaksanakan dan menindaklanjuti asesmen, kunjungan rumah, menyusun dan melaporkan program bimbingan dan konseling, membuat evaluasi, dan melaksanakan administrasi dan mekanisme bimbingan dan konseling, serta (2) kegiatan tambahan dan pengembangan profesi, bagi konselor atau guru kelas yang berfungsi sebagai guru bimbingan dan konseling, kegiatan pengembangan profesi dilaksanakan sesuai dengan tugasnya sebagai guru kelas dengan diperkaya oleh kegiatan pelatihan atau lokakarya tentang bimbingan dan konseling untuk memperkuat kompetensi dalam menjalankan fungsi sebagai guru bimbingan dan konseling ataukonselor.

Pengembangan Keprofesian Berkelanjutan (guru sebagai pembelajar) bagi konselor atau guru bimbingan dan konseling dapat dilakukan dengan moda tatap muka, daring dan kombinasi antara tatap muka dan daring.

\section{F. REFERENSI}

Junaedi, dan Wiryosutomo, Hadi Warsito. (2013). Hubungan Antara Persepsi Siswa Terhadap K ompetensi Kepribadian dan Kinerja Konselor dengan Minat Siswa untuk Memanfaatkan Layanan Bimbingan dan Konseling di Sekolah. Jurnal BK UNESA: Semarang.

Kartono, Kartini. 1985. Bimbingan dan Dasar-Dasar Pelaksanaannya. Jakarta: CV Rajawali. 
Prayitno dan Amti, E. (2004). Dasar-Dasar Bimbingan dan Konseling. Jakarta: Rineka Cipta.

Prayitno. (2004). Dasar-dasar Bimbingan dan Konseling. Jakarta: Rineka Cipta.

Suharsimi, Arikunto. (2006). Manajemen Penelitian. Jakarta: Rineka Cipta.

Sukardi, Dewa Ketut. (2003). Management Bimbingan dan Konseling di Sekolah. Bandung: Alfabeta.

Suherman. (2008). Konsep dan Aplikasi Bimbingan dan Konseling. Bandung: UPI. Ulvina

Tohirin. 2007. Bimbingan dan Konseling di Sekolah dan Madrasah Berbasis Intregrasi. Jakarta: RajaGrafindo Pers.

Kartono, Kartini. 1985. Bimbingan dan Dasar-Dasar Pelaksanaannya. Jakarta: CV Rajawali.

Prayitno., Emti, Erman. 1999. Dasar-Dasar Bimbingan Dan Konseling. Jakarta: PT. Rineka Cipta.

Yusuf, Samsu. (2009). Program Bimbingan dan Konseling di Sekolah. Bandung: Rizqi Press.

Adi Wibowo. 2019. "PENGGUNAAN MEDIA SOSIAL SEBAGAI TREND MEDIA DAKWAH PENDIDIKAN ISLAM DI ERA DIGITAL." JURNAL ISLAM NUSANTARA 3 (2).

Daimah \& Zainun Wafiqatun Niam. 2019. "LANDASAN FILOSOFIS PEMBELAJARAN AGAMA ISLAM PERSPEKTIF HEREDITAS, LINGKUNGAN, KEBEBASAN MANUSIA DAN INAYAH TUHAN." At-Tarbiyat:Jurnal Pendidikan Islam 2 (2). https:/ / doi.org/10.2105/ccdml.2868.002.

Eko Prayogo, Suyadi. 2019. "Pembelajaran Pendidikan Agama Islam di Era Revolusi 4.0.Dengan Pendekatan Humanistik di SMP Muhammadiyah Al Mujahidin Gunung Kidul." At-Tarbiyat:Jurnal Pendidikan Islam 2 (2). https://doi.org/10.2105/ccdml.2868.002.

Hardiyanti, Irawati, Hasgimianti, Nurhayati Zein, Musa Thahir. 2019. “Pengaruh Program Pendidikan dan Pelatihan terhadap Peningkatan Kompetensi Guru di SMP 
Negeri 1 Keritang." $\quad$ At-Tarbiyat:Jurnal Pendidikan Islam 2 (2). https://doi.org/10.2105/ccdml.2868.002.

Indhra Musthofa. 2019. "MODERNISASI PENDIDIKAN ISLAM PESANTREN DALAM TINJUAN FILOSOFIS METODOLOGIS." At-Tarbiyat:Jurnal Pendidikan Islam 2 (2). https:// doi.org/10.2105/ccdml.2868.002.

Moch. Tohet, Ida Rositha. 2019. "Penguatan Kurikulum 2013 dalam Menumbuhkan Karakter Peserta Didik di Sekolah." At-Tarbiyat:Jurnal Pendidikan Islam 1 (2): Editors2. https:/ / doi.org/10.1253/circrep.cr-1_editors2.

Sigit Santoso. 2019. "PERAN PESANTREN DALAM PENDIDIKAN RESOLUSI KONFLIK KEAGAMAAN." At-Tarbiyat:Jurnal Pendidikan Islam 2 (2). https://doi.org/10.2105/ccdml.2868.002.

Wibowo, Adi. 2018. "Study Komparasi Penyelenggaraan Pendidikan SMK ( Studi Kasus SMK Di Pondok Pesantren Lirboyo Al-Mahrusiyah Dan Di SMK PGRI 2." At-Tarbiyat:Jurnal Pendidikan Islam 1 (1): 1-15. 